\title{
A Novel Model of Murine Mucopolysaccharidosis Type VII due to an Intracisternal A Particle Element Transposition into the $\beta$-Glucuronidase Gene: Clinical and Pathologic Findings
}

\author{
CAROLE VOGLER, BETH LEVY, NANCY GALVIN, MARK S. SANDS, \\ EDWARD H. BIRKENMEIER, $\uparrow$ WILLIAM S. SLY, AND JANE BARKER \\ Department of Pathology [C.V., B.L., N.G.], The Edward A. Doisy Department of Biochemistry and \\ Molecular Biology [W.S.S.], St. Louis University School of Medicine, St. Louis, Missouri 63104, U.S.A.; \\ Department of Internal Medicine and Genetics, Washington University School of Medicine, St. Louis, \\ Missouri 63110, U.S.A. [M.S.S.]; and The Jackson Laboratory, Bar Harbor, Maine 04609, U.S.A.
} [E.H.B., J.B.]

\section{ABSTRACT}

We describe the clinical and pathologic findings in a murine model of mucopolysaccharidosis VII (Sly disease) that arose spontaneously in the $\mathrm{C} 3 \mathrm{H} / \mathrm{HeOuJ}$ mouse strain. Affected gus $^{\mathrm{mps} 2 \mathrm{~J}} / \mathrm{gus}^{\mathrm{mps} 2 \mathrm{~J}}$ mice are deficient in $\beta$-glucuronidase because of insertion of an intracisternal A particle element into intron 8 of the gus structural gene. This is the first model of a human lysosomal storage disease caused by an intracisternal A particle element insertion. Mice with the $g u s^{\mathrm{mps} 2 \mathrm{~J}} / \mathrm{gus}^{\mathrm{mps} 2 \mathrm{~J}}$ genotype have $<1 \%$ of normal $\beta$-glucuronidase activity and secondary elevations of other lysosomal enzymes. The phenotype includes shortened life-span, dysmorphic features, and skeletal dysplasia. Lysosomal storage of glycosaminoglycans is widespread and affects the brain, skeleton, eye, ear, heart valves, aorta, and the fixed tissue macrophage system. Thus the phenotypic and pathologic alterations in $g u s^{\mathrm{mps} 2 \mathrm{~J}} / \mathrm{gus}^{\mathrm{mps} 2 \mathrm{~J}}$ mice are similar to those in patients with mucopolysaccharidosis VII. The finding of antibodies to $\beta$-glucuronidase in some older $g u s^{\mathrm{mps} 2 \mathrm{~J}} / \mathrm{gus}^{\mathrm{mps} 2 \mathrm{~J}}$ mice suggests the mice produce sufficient enzyme to elicit an immune response. The $g u s^{\mathrm{mps} 2 \mathrm{~J}} / g u s^{\mathrm{mps} 2 \mathrm{~J}}$ model provides another welldefined genetic system for the study of the pathophysiology of mucopolysaccharidosis and for evaluation of experimental therapies for lysosomal storage diseases. The disease in $g u s^{\mathrm{mps} 2 \mathrm{~J} /}$ gus $^{\mathrm{mps} 2 \mathrm{~J}}$ mice is less severe than that seen in the previously characterized B6.C-H2 $2^{\mathrm{bm} 1} / \mathrm{ByBir}-g u s^{\mathrm{mps}} / g u s^{\mathrm{mps}}$ mouse model. Furthermore, unlike $g u s^{\mathrm{mps}} / g u s^{\mathrm{mps}}$ mice, $g u s^{\mathrm{mps} 2 \mathrm{~J}} / g u s^{\mathrm{mps} 2 \mathrm{~J}}$ mice are fertile and breed to produce litters, all of which are mucopolysaccharidosis VII pups. This feature makes them extremely useful for testing intrauterine therapies. (Pediatr Res 49: 342348,2001 )
MPS, mucopolysaccharidosis
LSD, lysosomal storage disease
GAG, glycosaminoglycan
GUSB, $\beta$-glucuronidase
IAP, intracisternal A particle

The MPSs are a group of LSDs characterized by a deficiency of a lysosomal acid hydrolase that degrades GAG. MPS patients with different enzyme deficiencies share clinical, pathologic, and biochemical features, including progressive lysosomal GAG accumulation and associated cellular and organ dysfunction. Premature death, mental retardation, coarse fa-

Received December 22, 1999; accepted August 22, 2000.

Correspondence and reprint requests: Carole Vogler, M.D., Department of Pathology, St. Louis University School of Medicine, 1402 S. Grand Blvd., St. Louis, MO 63104 U.S.A.

Supported by National Institutes of Health grants DK 41082, DK 49525 to J.B. and C.V., DK 40163, GM 34182 to W.S.S., and DK53920 to M.S.S.

†Deceased. cies, and widespread skeletal and joint abnormalities, collectively referred to as dysostosis multiplex and hepatosplenomegaly, are seen in most patients with MPS (1). MPS VII (Sly disease) is characterized by GUSB (EC 3.2.1.31) deficiency and clinical and pathologic features similar to those seen in other types of MPS (1-3).

Effective therapies for patients with LSD are limited, and experiments on meaningful numbers of genetically identical mice with LSD can provide useful information on the effect of treatments for these disorders (4). Animal models of LSD also allow detailed study of the pathophysiology of these disorders. Several spontaneously occurring models of MPS have been described and used to test therapies $(1,4)$. The ideal model has clinical findings and pathology that resemble those of human LSD and is hardy enough to survive therapy. 
We identified earlier a small, dysmorphic $\mathrm{C} 3 \mathrm{H} / \mathrm{HeOuJ}$ male mouse homozygous for a spontaneous mutation, $g u s^{\mathrm{mps} 2 \mathrm{~J}}$, in the GUSB structural gene, which results in $<1 \%$ normal GUSB activity (5). Affected offspring of the mouse have markedly reduced GUSB mRNA and secondary elevation of other lysosomal enzymes. The mutation is caused by a $5.4-\mathrm{kb}$ IAP element insertion into intron 8 of the structural gene for GUSB on chromosome 5 (5). The IAP insertion correlates with a dramatic reduction in the amount of normal size gus mRNA and the presence of a truncated gus mRNA expressed at 5- to 7-fold less than normal (5). This is the first LSD model caused by insertion of an IAP into the structural gene for a lysosomal enzyme. Murine IAPs are defective retrovirons encoded by a family of endogenous proviral elements; their transposition into genes can alter transcription.

The gus $^{\mathrm{mps} 2 \mathrm{~J}} /$ gus $^{\mathrm{mps} 2 \mathrm{~J}}$ mice have a progressive clinical course and pathologic features, including shortened life span, skeletal dysostosis, and widespread lysosomal storage with marked lysosomal distention in the fixed tissue macrophage system and skeleton. These clinical and pathologic findings parallel those of humans with MPS. The phenotype of the $g u s^{\mathrm{mps} 2 \mathrm{~J}} / g u s^{\mathrm{mps} 2 \mathrm{~J}}$ mouse is similar to, although less severe than, that seen in a previously described model of murine MPS VII $(6,7)$ with a 1-bp deletion in exon 10 of the gus gene (8).

\section{METHODS}

Clinical comparisons of $\mathrm{C} 3 \mathrm{H} / \mathrm{HeOuJ}-g_{u s}{ }^{\mathrm{mps}} 2 \mathrm{~J} / g u s^{\mathrm{mps} 2 \mathrm{~J}}$ affected mice and phenotypically normal gus ${ }^{\mathrm{mps} 2 \mathrm{~J}} /+$ mice maintained at The Jackson Laboratory were performed since 1992. All mice were handled with the highest standards of humane animal care. The Jackson Laboratory Animal Care and Use Committee approved the study we performed. This committee is the applicable institutional review board at The Jackson Laboratory. The Jackson Laboratory is fully accredited by the American Association for the Accreditation of Laboratory Animal Care. The gus $^{\mathrm{mps} 2 \mathrm{~J}} / \mathrm{gus}^{\mathrm{mps} 2 \mathrm{~J}}$ mice were identified by measuring GUSB levels in tail tissue. Eighteen male and 26 female $g u s^{\mathrm{mps} 2 \mathrm{~J}} / \mathrm{gus}^{\mathrm{mps} 2 \mathrm{~J}}$ mice born before 1995 and six male and 19 females born after 1994 were followed to determine survival. Survival was compared using the $t$ test. Groups of phenotypically normal gus $^{\mathrm{mps} 2 \mathrm{~J}} /+$ males $(n=22)$ and females $(n=7)$ and of $g u s^{\mathrm{mps} 2 \mathrm{~J}} / g u s^{\mathrm{mps} 2 \mathrm{~J}}$ males $(n=14)$ and females $(n=14)$ were weighed at intervals from birth $(0 \mathrm{~d})$ to $>1 \mathrm{mo}$ of age.

Nineteen $g u s^{\mathrm{mps} 2 \mathrm{~J}} / g u s^{\mathrm{mps} 2 \mathrm{~J}}$ and eight phenotypically normal mice from 1 to 19 mo old obtained before 1995 were killed by asphyxiation, and organs were sampled for histology. Tissue was fixed in $2 \%$ glutaraldehyde in $4 \%$ paraformaldehyde in PBS and postfixed in $1 \%$ osmium tetroxide. Samples of liver, spleen, kidney, skin, heart, aorta, bone and cartilage at the costochondral junction, and brain including hippocampus, parietal cortex and subcortical white matter, and cerebellum were prepared and studied by light or electron microscopy as previously described (7).

The skeletons, including dissected long bones and skulls, were radiographed using a Faxitron Radiographic Analyzer. (Hewlett Packard, McMinnville, Oregon, U.S.A.) Images of forelimb bones of three normal and six $g u s^{\mathrm{mps} 2 \mathrm{~J}} / g u s^{\mathrm{mps} 2 \mathrm{~J}}$ male adult mice were measured to evaluate long bone growth. The long bones from 3, 6, and 12 mo old mice were decalcified, routinely processed, and stained with hematoxylin and eosin and alcian blue-periodic acid-Schiff to identify tissue GAG histologically (7). The external and middle ears from the same mice were dissected, fixed in $4 \%$ neutral buffered formalin, decalcified, and sectioned as previously described (9).

Eighteen $g u s^{\mathrm{mps} 2 \mathrm{~J}} / \mathrm{gus}^{\mathrm{mps} 2 \mathrm{~J}}$ mice $>1$ y (16 maintained by M.S.S., two maintained by E.H.B.) and eight $g u s^{\mathrm{mps} 2 \mathrm{~J}} / g u s^{\mathrm{mps} 2 \mathrm{~J}}$ mice $\leq 1$ y of age maintained by J.B. were evaluated using an ELISA technique as previously described (10) for antibodies to GUSB. Samples of intestine, brain, and liver of 16 of the mice $>1$ y of age were frozen, sectioned, and stained with a histochemical technique to demonstrate GUSB activity (10).

\section{RESULTS}

The gus $^{\mathrm{mps} 2 \mathrm{~J}} / \mathrm{gus}^{\mathrm{mps} 2 \mathrm{~J}}$ mice were dysmorphic with growth retardation, a blunted facies, and short limbs (Fig. 1). Dysmorphic features were readily apparent in weanling mice. Male $g u s^{\mathrm{mps} 2 \mathrm{~J}} / g u s^{\mathrm{mps} 2 \mathrm{~J}}$ mice weights were similar to normal from 1 to $21 \mathrm{~d}$ of age. At weaning, the affected males tended to weigh less than normal, and as they aged, the difference in weight was

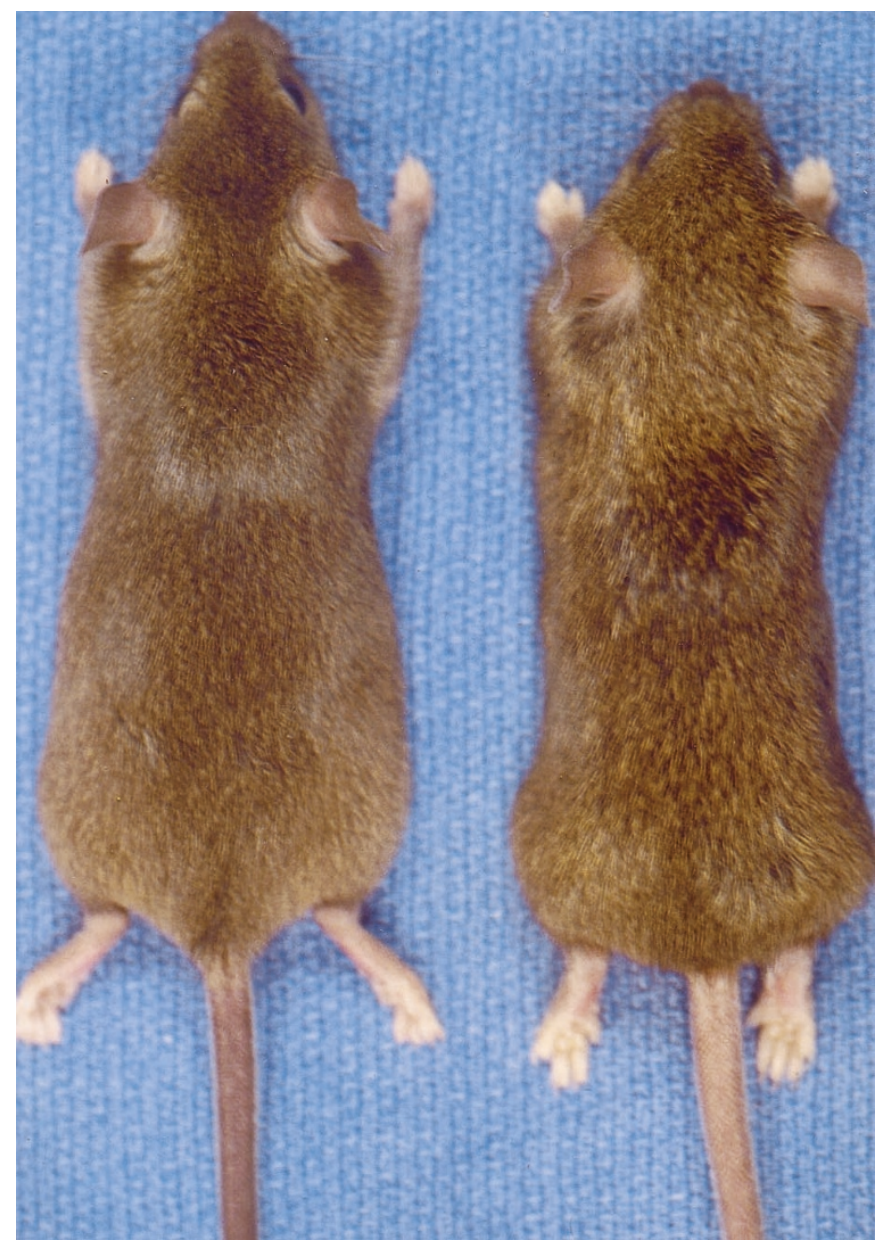

Fig. 1. A 1-y-old $g u s^{\mathrm{mps} 2 \mathrm{~J}} / g u s^{\mathrm{mps} 2 \mathrm{~J}}$ mouse (right) is easily distinguished from its littermate (left) by its small size, short blunted nose, short limbs, and thick tail. 
maintained (Fig. 2). Females weighed less than males, and the affected females, like the affected males, weighed less than normal females after weaning. Average survival of $44 \mathrm{gus} \mathrm{mps}^{\mathrm{J}} /$ gus $^{\mathrm{mps} 2 \mathrm{~J}}$ mice born between 1992 and 1994 was $431 \mathrm{~d}$ (Fig. 3). For 25 mice, all of the same $g u s^{\mathrm{mps} 2 \mathrm{~J}} / \mathrm{gus}^{\mathrm{mps} 2 \mathrm{~J}}$ strain, but born between 1995 and 1997, average life-span was 187 d. Females were, on average, shorter lived than males.

Radiographic alterations in skeletons of $g u s^{\mathrm{mps} 2 \mathrm{~J}} / g u s^{\mathrm{mps} 2 \mathrm{~J}}$ mice included wide oar-shaped ribs, a shortened wide pelvis, broad, short limbs, particularly proximal long bones, and a generalized increase in bone radiodensity (Fig. 4). In adult $g u s^{\mathrm{mps} 2 \mathrm{~J}} / \mathrm{gus}^{\mathrm{mps} 2 \mathrm{~J}}$ mice, the humerus was $85 \%$ of normal bone length and the radius-ulna, $94 \%$ of normal.

There was histologic evidence of lysosomal storage in all tissues examined, although the amount of storage varied from cell to cell and among mice. The fixed tissue macrophage system was affected with cytoplasmic vacuolization in Kupffer cells (Fig. 5A), spleen, and bone marrow sinus-lining cells. Ultrastructurally, the vacuoles had a single membrane, and the stored material was fine fibrillogranular with associated large electron dense granules (Fig. $5 B$ ). When the fibrillogranular material was lost in processing, vacuoles appeared empty. Hepatocytes did not have lysosomal storage. Spleen lymphocytes were only occasionally affected with a small amount of vacuolization.

Glomerular visceral and parietal epithelial cells and renal tubular epithelial cells had lysosomal distention. Skin storage was primarily in the dermal fibroblasts and in s.c. fat cells. The heart valves contained vacuolated stromal cells; scattered perivascular cells distended by vacuoles were seen in the myocardium, but myocytes contained no storage. Aortic medial and endothelial cells were distended by storage.

The ears of the $g u s^{\mathrm{mps} 2 \mathrm{~J}} / \mathrm{gus}^{\mathrm{mps} 2 \mathrm{~J}}$ mice were markedly altered, showing changes similar to those previously described in the gus $^{\mathrm{mps}} / \mathrm{gus}^{\mathrm{mps}}$ MPS VII model (Fig. 6) (9). Several $g u s^{\mathrm{mps} 2 \mathrm{~J}} / g u s^{\mathrm{mps} 2 \mathrm{~J}}$ mice had otitis media with associated thickening of the connective tissue of the middle ear mucosa. The tympanic membrane was thickened and ossicles were altered with vacuolization of chondrocytes and osteocytes and expansion of the osseous lacunae. Bone in other sites was also

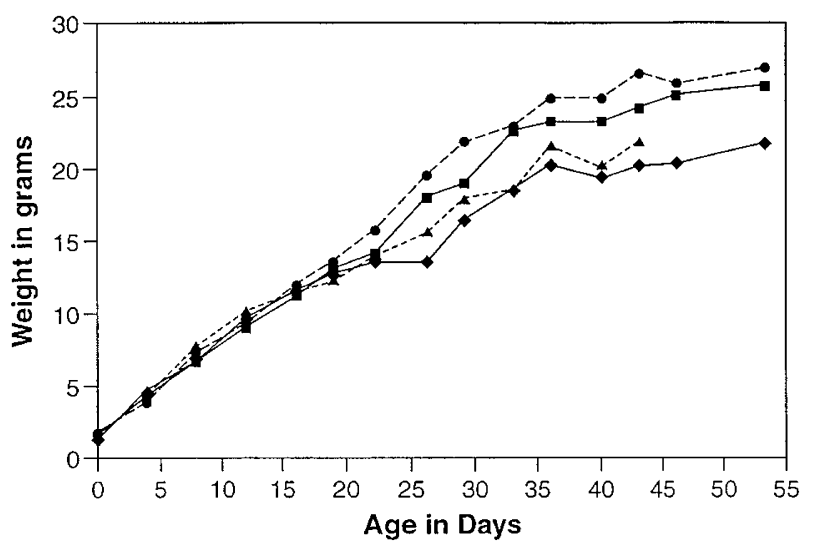

Fig. 2. The weight of MPS VII males ( $\square$ ) and females $(\bullet)$ tended to be less than that of phenotypically normal male $(\mathbf{O})$ and female $(\mathbf{\Delta})$ mice near weaning and thereafter.

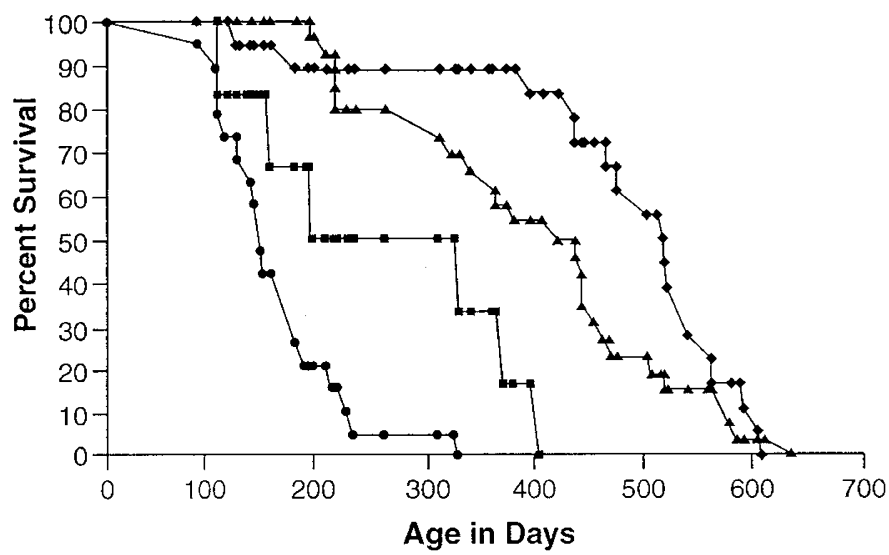

Fig. 3. Survival of the $g u s^{\mathrm{mps} 2 \mathrm{~J}} / g u s^{\mathrm{mps} 2 \mathrm{~J}}$ mice is shorter than that of normal mice. Phenotypically normal mice live approximately $604 \mathrm{~d}$. The $g u s^{\mathrm{mps} 2 \mathrm{~J} /}$ gus $^{\text {mps2J }}$ colony had a mean survival of $431 \mathrm{~d}$ for mice [ $\Delta$ females, $428 \mathrm{~d} \pm$ $130 \mathrm{~d}$ (mean $\pm \mathrm{SEM}) ; \diamond$ males, $476 \mathrm{~d} \pm 132 \mathrm{~d}$ ] born before 1995. Although of the same strain, gus ${ }^{\mathrm{mps} 2 \mathrm{~J}} / \mathrm{gus}^{\mathrm{mps} 2 \mathrm{~J}}$ mice born during and after 1995 had a shorter mean survival of only $187 \mathrm{~d}(\bullet$ females, $150 \mathrm{~d} \pm 58 \mathrm{~d}$; $\mathbf{\square}$ males, $262 \mathrm{~d}$ $\pm 122 \mathrm{~d}$ ). The cause of this change in survival over time (females, $p<0.01$; males, $p=0.002$ ) is unknown and was not observed in another colony housed outside of The Jackson Laboratory.

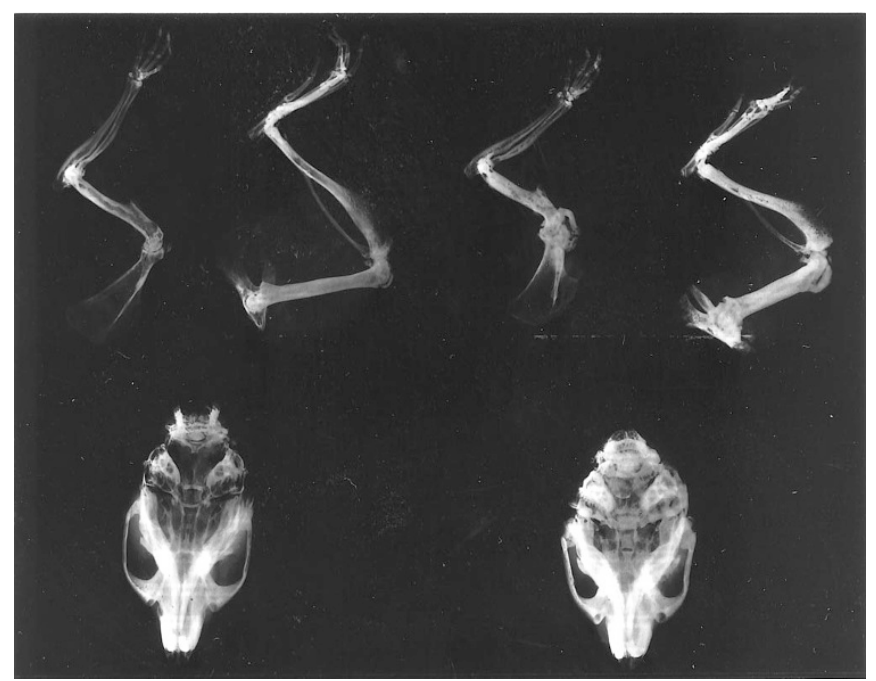

Fig. 4. The skull of a 1 -y-old $g u s^{\mathrm{mps} 2 \mathrm{~J}} / g u s^{\mathrm{mps} 2 \mathrm{~J}}$ mouse (right) is shorter with thickened broad zygomatic arch and diffuse increase in radiodensity compared with an age-matched phenotypically normal mouse (left). The long bones are thickened, broad, and short in the gus ${ }^{\mathrm{mps} 2 \mathrm{~J}} / \mathrm{gus}^{\mathrm{mps} 2 \mathrm{~J}}$ mouse (right) compared with the same bones in a normal mouse (left).

abnormal with marked lysosomal distention in osteoblasts, osteocytes, and chondrocytes (Fig. 7). The synovium of large stifle joints was proliferated with marked stromal cell vacuolization and GAG accumulation.

The corneal fibroblasts in $g u s^{\mathrm{mps} 2 \mathrm{~J}} / g u s^{\mathrm{mps} 2 \mathrm{~J}}$ mice had a moderate amount of cytoplasmic vacuolization, but retinal pigment epithelium had no lysosomal distention. Phenotypically normal mice of the $\mathrm{C} 3 \mathrm{H} / \mathrm{HeOuJ}$ strain, on which the gus $^{\text {mps2J }}$ mutation arose, have photoreceptor degeneration, a finding also seen in the $g u s^{\mathrm{mps} 2 \mathrm{~J}} / \mathrm{gus}^{\mathrm{mps} 2 \mathrm{~J}}$ mice of this strain.

In the CNS, lysosomal distention was seen in leptomeningeal, parenchymal perivascular, and glial cells and neocortical (Fig. 8A) and hippocampal (Fig. 8B) cortex neurons. The amount of lysosomal storage in different neuronal groups 


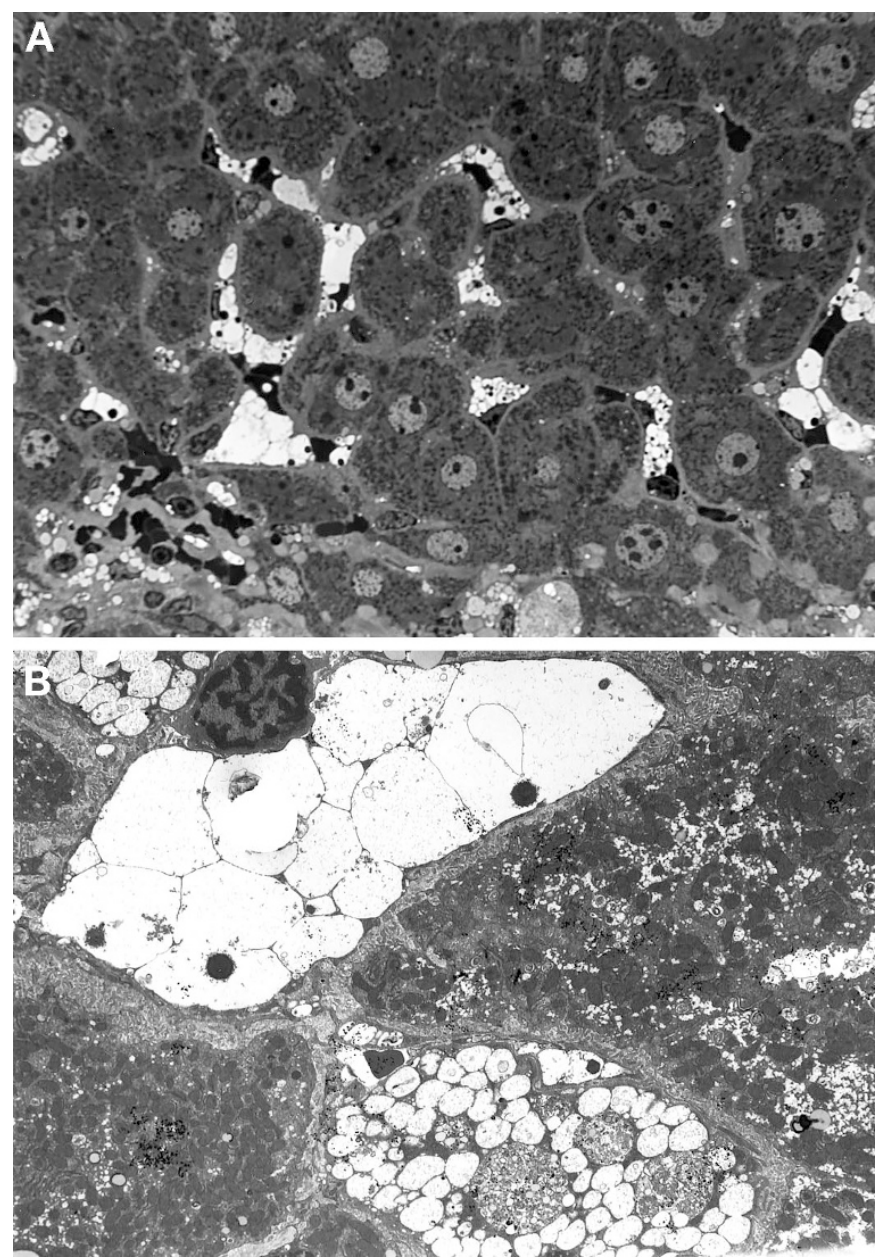

Fig. 5. A, liver Kupffer cells from a 6-mo-old $g u s^{\mathrm{mps} 2 \mathrm{~J}} / g u s^{\mathrm{mps} 2 \mathrm{~J}}$ mouse have lysosomal distention, which is variable in amount but apparent in all mice examined. Hepatocytes have no lysosomal distention (toluidine blue, $\times 543$ ). $B$, ultrastructurally, gus ${ }^{\mathrm{mps} 2 \mathrm{~J}} / \mathrm{gus}^{\mathrm{mps} 2 \mathrm{~J}}$ mice have Kupffer cells in the liver with marked lysosomal distention by fine fibrillogranular storage material as well as electron dense granules (uranyl acetate-lead citrate, $\times 2450$ ).

varied among age-matched $g u s^{\mathrm{mps} 2 \mathrm{~J}} / g u s^{\mathrm{mps} 2 \mathrm{~J}}$ mice and did not always correlate with the animal's age except in the hippocampus.

Before age $6 \mathrm{mo}$, the amount of storage throughout the hippocampus was sparse, without a clear gradient. After 6 mo, relative sparing of the pyramidal neurons in $\mathrm{CA}_{1}$ sector of the hippocampal formation was apparent, but storage elsewhere in the hippocampus increased with age and was maximal at $1 \mathrm{y}$ of age.

The cerebellar cortex Purkinje cells contained abundant electron-dense flocculent storage material (Fig. 8, $C$ and $D$ ) similar to that previously described in another MPS VII model (11). Storage was not progressive after 3 mo of age. Meganeurites were prominent in the affected mice, appearing at $3 \mathrm{mo}$ of age; they were most numerous in the oldest mice examined (14 and 19 mo of age) and occurred in both the hippocampal cortex and neocortex.

Seven of the $18 \mathrm{gus}^{\mathrm{mps} 2 \mathrm{~J}} / \mathrm{gus}^{\mathrm{mps} 2 \mathrm{~J}}$ mice $>1 \mathrm{y}$ of age had antibodies to GUSB detected by ELISA. None of the younger $g_{u s}{ }^{\mathrm{mp} 2 \mathrm{~J}} / \mathrm{gus}^{\mathrm{mps} 2 \mathrm{~J}}$ mice had demonstrable antibody. GUSB was not quantitated in tissue, but there were no GUSB-containing cells identified in the $16 \mathrm{gus}^{\mathrm{mps} 2 \mathrm{~J}} / \mathrm{gus}^{\mathrm{mps} 2 \mathrm{~J}}$ mice examined histochemically.

\section{DISCUSSION}

Marked phenotypic heterogeneity has been noted in human MPS VII (1). This report illustrates heterogeneity in murine MPS VII as well. The gus ${ }^{\mathrm{mps} 2 \mathrm{~J}} /$ gus $^{\mathrm{mps} 2 \mathrm{~J}}$ mice have a less severe disease than that of the previously described $g u s^{\mathrm{mps}} / g u s^{\mathrm{mps}}$ mice (7). The $g u s^{\mathrm{mps} 2 \mathrm{~J}} / g u s^{\mathrm{mps} 2 \mathrm{~J}}$ mice are able to bear live young and raise them to weaning, whereas $g u s^{\mathrm{mps}} / g u s^{\mathrm{mps}}$ mice conceive with difficulty, rarely carry litters to term (12), and do not lactate. Whether the milder phenotype of $g u s^{\mathrm{mps} 2 \mathrm{~J}} / g u s^{\mathrm{mps} 2 \mathrm{~J}}$ mice is associated with comparably milder functional deficits than those observed in $g u s^{\mathrm{mps}} / g u s^{\mathrm{mps}}$ mice (13-15) has not yet been evaluated.

When first observed, the $g u s^{\mathrm{mps} 2 \mathrm{~J}} / g u s^{\mathrm{mps} 2 \mathrm{~J}}$ mice had a much longer average life-span $\left(431\right.$ d) than $g u s^{\mathrm{mps}} / g u s^{\mathrm{mps}}$ mice (139-170 d). Since 1995, an unexplained decrease in survival to an average of $187 \mathrm{~d}$ was noted for $g u s^{\mathrm{mps} 2 \mathrm{~J}} / g u s^{\mathrm{mps} 2 \mathrm{~J}}$ mice maintained at The Jackson Laboratory (Fig. 3). An environmental change (e.g. handling, nutrition, infection) may have contributed to the recent change in survival of the gus ${ }^{\mathrm{mps} 2 \mathrm{~J}} /$ $g_{u s}{ }^{\text {mps2J }}$ mice observed at The Jackson Laboratory. This change in survival of mice maintained at The Jackson Laboratory correlated with a change from Wayne Grain to National Institutes of Health-31 diet, but further investigations are necessary to determine what environmental factor, if any, has a role in the survival of the $\mathrm{g} u s^{\mathrm{mps} 2 \mathrm{~J}} / g u s^{\mathrm{mps} 2 \mathrm{~J}}$ strain. $g u s^{\mathrm{mps} 2 \mathrm{~J} /}$ gus $^{\mathrm{mps} 2 \mathrm{~J}}$ mice maintained by M.S.S. at Washington University on a diet similar in fat content to Wayne Grain have an average life-span of approximately 1 y (data not shown).

The ultrastructural character of lysosomal GAG accumulation is similar in both MPS VII models, although, overall, lysosomal distention is less prominent in the $g u s^{\mathrm{mps} 2 \mathrm{~J}} / g u s^{\mathrm{mps} 2 \mathrm{~J}}$ mice. The brain in the $g u s^{\mathrm{mps} 2 \mathrm{~J}} / g u s^{\mathrm{mps} 2 \mathrm{~J}}$ mice has striking meganeurite formation, seen only occasionally in $g u s$ mps/ $g_{u s}{ }^{\mathrm{mps}}$ mice (11). Meganeurites are structural alterations of the neuronal axon hillock-initial axon segment and contain undegraded substrate. They are described in both human and animal LSD (11) and are thought to interfere with cell function by altering electrical properties of neurons (16).

The relative lack of lysosomal storage in neurons in $\mathrm{CA}_{1}$ of the hippocampus is similar to that seen in the $g u s{ }^{\mathrm{mps}} / g u s^{\mathrm{mps}}$ mice, and in humans with MPS VII and IV (11). The variability in amount of storage in neuronal groups may reflect sitespecific differences in GUSB dependency for GAG turnover. Unlike $g u s^{\mathrm{mps}} /$ gus $^{\mathrm{mps}}$ MPS VII mice, gus ${ }^{\mathrm{mps} 2 \mathrm{~J}} / g u s^{\mathrm{mps} 2 \mathrm{~J}}$ mice have no retinal pigment epithelium storage. This may be related to the photoreceptor loss characteristic of the $\mathrm{C} 3 \mathrm{H}$ strain. Retinal pigment epithelium has a role in outer segment photoreceptor turnover, and without photoreceptors, GUSB deficiency may not result in GAG storage.

The phenotypic differences between the two inbred mouse strains, gus ${ }^{\mathrm{mps} 2 \mathrm{~J}} / \mathrm{gus}^{\mathrm{mps} 2 \mathrm{~J}}$ and $\mathrm{g} u s^{\mathrm{mps}} / \mathrm{gus}^{\mathrm{mps}}$, may be the result of genetic modifiers on the $\mathrm{C} 3 \mathrm{H}$ background that modulate expression of GUSB deficiency in $g u s^{\mathrm{mps} 2 \mathrm{~J}} / g u s^{\mathrm{mps} 2 \mathrm{~J}}$ mice. 

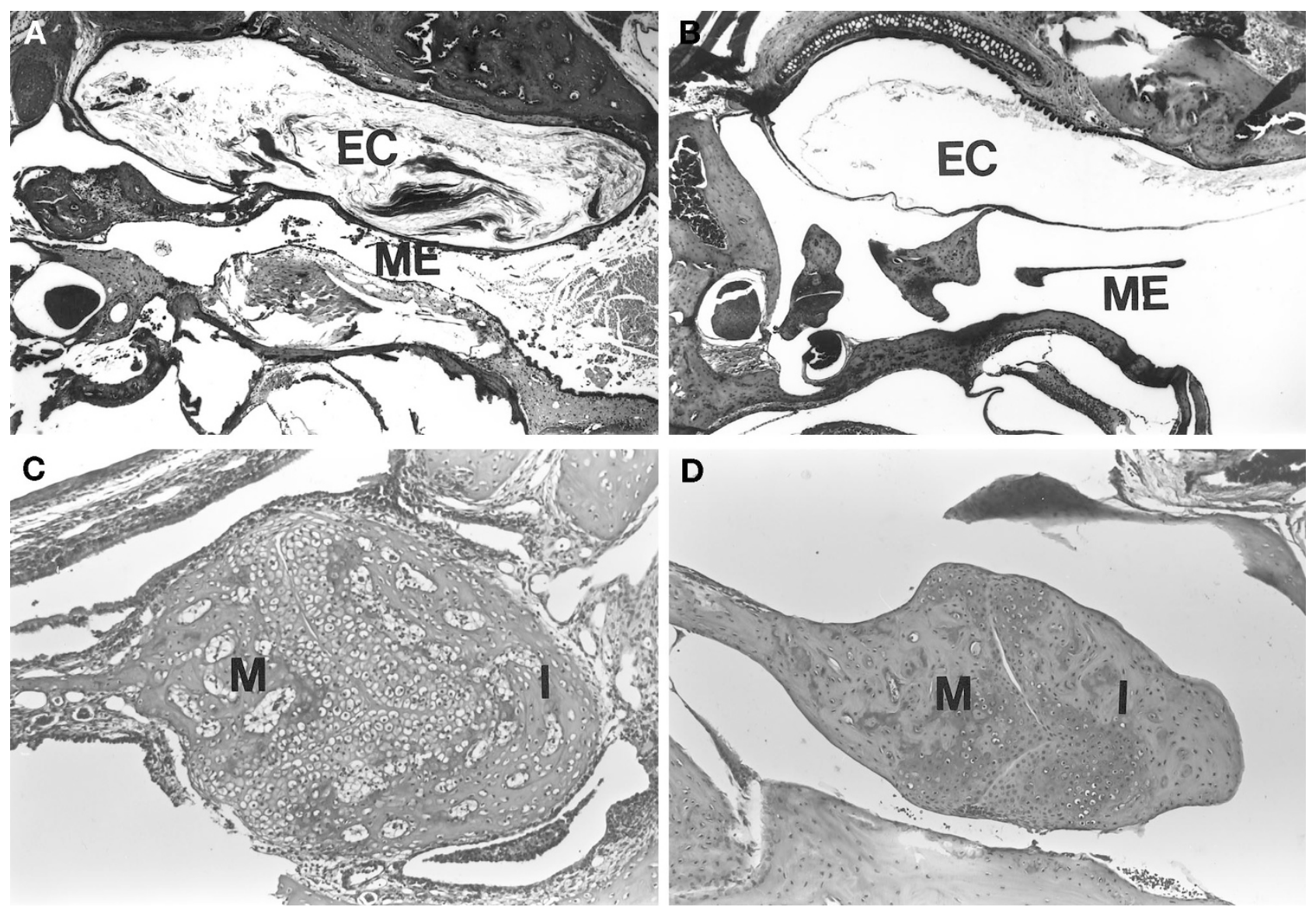

Fig. 6. $A$, ear of a 6-mo-old $g u s^{\mathrm{mps} 2 \mathrm{~J}} / \mathrm{gus}^{\mathrm{mps} 2 \mathrm{~J}}$ mouse has laminated keratin in the external auditory canal (EC), a thick tympanic membrane, and otitis in the middle ear cavity $(M E) . B$, same area of the EC and ME from a normal littermate is histologically normal. $C$, malleus $(M)$ and incus $(I)$ of the middle ear of a 3-mo-old $g u s^{\mathrm{mps} 2 \mathrm{~J}} / \mathrm{gus}^{\mathrm{mps} 2 \mathrm{~J}}$ mouse has bone dysplasia similar to that seen in the other bones, with distention of osteocytes and chondrocytes by enlarged lysosomes and expansion of the lacunae. The ossicles are adhered to the adjacent middle ear mucosa. $D$, same ossicles from a phenotypically normal littermate have no alteration in the osteocytes or chondrocytes (hematoxylin and eosin; $A, B: \times 32 ; C, D: \times 84$ ).

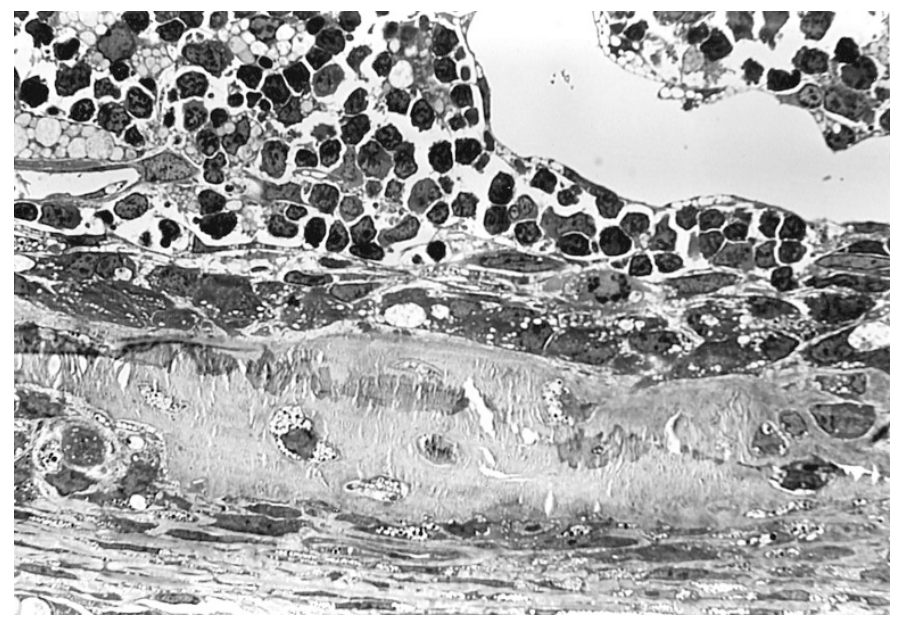

Fig. 7. The cortical bone from the rib of a 1-mo-old $g u s^{\mathrm{mps} 2 \mathrm{~J}} / g u s^{\mathrm{mps} 2 \mathrm{~J}}$ mouse has osteocyte and osteoblast vacuolization. The sinus lining cells in the adjacent bone marrow have minimal lysosomal distention (toluidine blue, $\times 543)$.

Wild-type $\mathrm{C} 3 \mathrm{H}$ mice have only $10 \%$ to $38 \%$ of the GUSB activity seen in wild-type B6 mice (5). The reduced GUSB activity may allow other pathways of GAG metabolism to develop in the $\mathrm{C} 3 \mathrm{H} / \mathrm{HeOuJ}$ mice, thus partially compensating for the marked reduction in GUSB. On the other hand, residual
GUSB activity in the $g u s^{\mathrm{mps} 2 \mathrm{~J}} / g u s^{\mathrm{mps} 2 \mathrm{~J}}$ mouse kidney is $0.5 \%$ the level found in the $\mathrm{C} 3 \mathrm{H} / \mathrm{HeOuJ}+/+$ mice compared with $0.005 \%$ of wild-type B6 levels in gus $^{\mathrm{mps}} / \mathrm{gus}^{\mathrm{mps}}$ mice. Possibly, the greater residual activity moderates consequences of the deficiency and contributes to the milder phenotype. Breeding the gus $^{\mathrm{mps}}$ mutation onto the $\mathrm{C} 3 \mathrm{H} / \mathrm{HeOuJ}$ background (17) and the $g u s^{\mathrm{mps} 2 \mathrm{~J}}$ mutation onto the B6 background could help distinguish the contribution to enzyme deficiency and strainspecific modifying genes on the different phenotypes.

The appearance of GUSB antibody in some animals was an unexpected and very interesting finding. It raises the possibility that the $g u s^{\mathrm{mps} 2 \mathrm{~J}}$ gene presumably silenced by the IAP element insertion might be activated over time in some cells and produce enzyme that is recognized as foreign by the mouse, naïve to this antigen at birth. Consistent with this hypothesis is the observation by Gwynn et al. (5) that one of five $g u s^{\mathrm{mps} 2 \mathrm{~J}} /$ gus $^{\mathrm{mps} 2 \mathrm{~J}}$ mice tested had an inexplicably high level of GUSB activity limited to the brain. What impact GUSB activity or antibodies to GUSB may have on survival of $\mathrm{g} u s^{\mathrm{mps} 2 \mathrm{~J}} / \mathrm{gus}^{\mathrm{mps} 2 \mathrm{~J}}$ mice requires further study. In long-term therapeutic studies using the $\mathrm{g} u \mathrm{~s}^{\mathrm{mps} 2 \mathrm{~J}} / \mathrm{gus} \mathrm{mps}^{\mathrm{mJ}}$ mice, evaluation of GUSB enzyme and antibody levels will be important.

Therapies for LSD in humans have included bone marrow transplantation and enzyme replacement (18). Animal models 

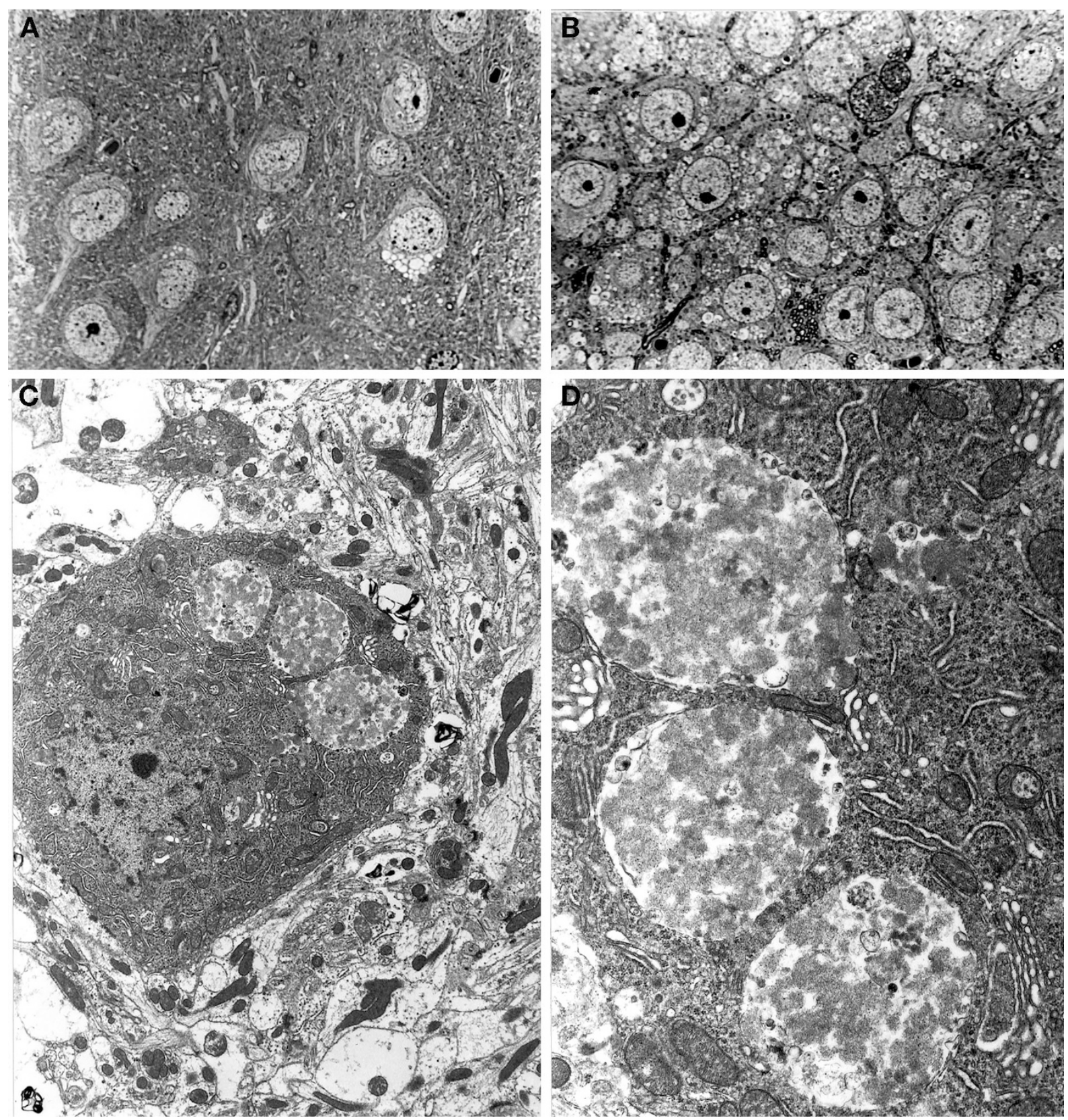

Fig. 8. The adult $g u s^{\mathrm{mps} 2 \mathrm{~J}} / \mathrm{gus}^{\mathrm{mps} 2 \mathrm{~J}}$ mice have widespread but mild neuronal lysosomal storage, here in a 1-y-old mouse cortex $(A)$ and hippocampus $(B)$.

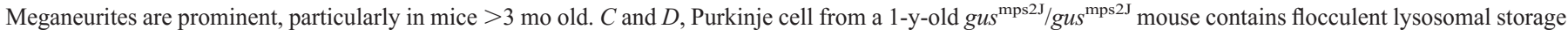
material $(A, B$ : toluidine blue $\times 543 ; C$, $D$ : uranyl acetate-lead citrate, $C: \times 4,402, D: \times 12,250)$.

have provided useful information on potential therapies for LSD $(1,4)$. The gus $^{\mathrm{mps} 2 \mathrm{~J}} / \mathrm{gus}^{\mathrm{mps} 2 \mathrm{~J}}$ mice offer several advantages in evaluating effects of various therapies. Because the $g u s^{\mathrm{mps} 2 \mathrm{~J}} / g u s^{\mathrm{mps} 2 \mathrm{~J}}$ mice breed, larger numbers of MPS VII mice can be produced from matings of homozygous parents than of heterozygous matings. In addition, because all pups in $g u s^{\mathrm{mps} 2 \mathrm{~J}} / g u s^{\mathrm{mps} 2 \mathrm{~J}}$ matings are MPS VII (rather than one in four in the $g u s^{\mathrm{mps}} /+$ matings), it is much easier to test the efficacy of in utero therapies such as enzyme replacement, stem cell transplantation, and gene therapy on MPS VII fetuses. Because pathologic alterations in LSD are already present in newborn mice (7), the most effective treatment for LSD may require initiation of therapy in utero. This report provides clinical and pathologic information that will be a useful benchmark for evaluation of such therapeutic strategies in the $g u s^{\mathrm{mps} 2 \mathrm{~J} /}$ gus $^{\mathrm{mps} 2 \mathrm{~J}}$ mouse.

\section{REFERENCES}

1. Neufeld EF, Muenzer J 1995 The mucopolysaccharidoses. In: Scriver CR, Beaudet AL, Sly WS, Valle D (eds) The Metabolic and Molecular Bases of Inherited Disease. McGraw-Hill, New York, pp 2465-2494

2. Sly WS, Quinton BA, McAlister WH, Rimoin DL 1973 Beta glucuronidase deficiency: report of clinical, radiologic, and biochemical features of a new mucopolysaccharidosis. J Pediatr 82:249-257

3. Vogler C, Levy B, Kyle JW, Sly WS, Williamson J, Whyte MP 1994 Mucopolysaccharidosis VII: postmortem biochemical and pathological findings in a young adult with $\beta$-glucuronidase deficiency. Mod Pathol 7:132-137 
4. Vogler C, Sands MS, Galvin N, Levy B, Thorpe C, Barker J, Sly WS 1998 Murine mucopolysaccharidosis type VII: the impact of therapies on the clinical course and pathology in a murine model of lysosomal storage disease. J Inher Metab Dis 21:575-586

5. Gwynn B, Lueders K, Sands MS, Birkenmeier EH 1998 Intracisternal A-particle element transposition into the murine $\beta$-glucuronidase gene correlates with loss of enzyme activity: a new model for $\beta$-glucuronidase deficiency in the $\mathrm{C} 3 \mathrm{H}$ mouse. $\mathrm{Mo}$ Cell Biol 18:6474-6481

6. Birkenmeier EH, Davisson MT, Beamer WG, Ganschow RE, Vogler CA, Gwynn B, Lyford KA, Maltais LM, Wawrzyniak CJ 1989 Murine mucopolysaccharidosis type VII: characterization of a mouse with $\beta$-glucuronidase deficiency. J Clin Inves $83: 1258-1266$

7. Vogler C, Birkenmeier EH, Sly WS, Levy B, Pegors C, Kyle JW, Beamer WG 1990 A murine model of mucopolysaccharidosis VII: gross and microscopic findings in beta-glucuronidase-deficient mice. Am J Pathol 136:207-217

8. Sands MS, Birkenmeier EH 1993 A single-base-pair deletion in the $\beta$-glucuronidase gene accounts for the phenotype of murine mucopolysaccharidosis type VII. Proc Natl Acad Sci USA 90:6567-6571

9. Berry CL, Vogler C, Galvin NJ, Birkenmeier EH, Sly WS 1994 Pathology of the ear in murine mucopolysaccharidosis type VII: morphologic correlates of hearing loss. Lab Invest 71:438-445

10. Sands MS, Vogler C, Torrey A, Levy B, Gwynn B, Grubb J, Sly WS, Birkenmeier EH 1997 Murine mucopolysaccharidosis type VII: long term therapeutic effects of enzyme replacement and enzyme replacement followed by bone marrow transplantation. J Clin Invest 99:1596-1605

11. Levy B, Galvin N, Vogler C, Birkenmeier EH, Sly WS 1996 Neuropathology of murine mucopolysaccharidosis type VII. Acta Neuropathol 92:562-568

12. Soper BW, Pung AW, Vogler CA, Grubb JH, Sly WS, Barker JE 1999 Enzyme replacement therapy improves reproductive performance in mucopolysaccharidosis type VII mice but does not prevent perinatal loses. Pediatr Res 45:180-186

13. Chang PL, Lambert DT, Pisa MA 1993 Behavioural abnormalities in a murine model of human lysosomal storage disease. Neuroreport 4:507-510

14. Sands MS, Erway LC, Vogler C, Sly WS, Birkenmeier EH 1995 Syngeneic bone marrow transplantation reduces the hearing loss associated with murine mucopolysaccharidosis type VII. Blood 86:2033-2040

15. O'Connor LH, Erway LC, Vogler CA, Sly WS, Nicholes A, Grubb J, Holmberg SW, Levy B, Sands MS 1998 Enzyme replacement therapy for murine mucopolysaccharidosis type VII leads to improvements in behavior and auditory function. J Clin Invest 101:1394-1400

16. Purpura DP, Suzuki K 1976 Distortion of neuronal geometry and formation of aberrant synapses in neuronal storage disease. Brain Res 116:1-21

17. Casal ML, Wolfe JH 1998 Variant clinical course of mucopolysaccharidosis type VII in two groups of mice carrying the same mutation. Lab Invest 78:1575-1581

18. Beutler E, Kay A, Saven A, Garver P, Thurston D, Dawson A, Rosenbloom B 1991 Enzyme replacement therapy for Gaucher disease. Blood 78:1183-1189 